Instructions for authors, subscriptions and further details:

http://mcs.hipatiapress.com

\title{
In the Pursuit of an Identity: Analysing the Case of Male Health Care Providers
}

Anakha Ajith ${ }^{1}$

University of Hyderabad, India

Date of publication: October $21^{\text {st }}, 2020$

Edition period: October 2020- February 2021

To cite this article: Ajith, A. (2020). In the Pursuit of an Identity: Analysing the Case of Male Health Care Providers, Masculinities and Social Change,6(3).310-336. https://doi.org/ 10.17583/MCS.2020.5461

To link this article: https://doi.org/ 10.17583/MCS.2020.5461

\section{PLEASE SCROLL DOWN FOR ARTICLE}

The terms and conditions of use are related to the Open Journal System and to Creative Commons Attribution License(CC-BY). 


\title{
In the Pursuit of an Identity:
}

\section{Analysing the Case of Male Health Care Providers}

\author{
Anakha Ajith \\ University of Hyderabad
}

\begin{abstract}
Being a female-concentrated job, nursing has forgotten the place of men within the profession despite their contribution since time immemorial. The heightened efforts of Florence Nightingale to transform nursing into a respectable female occupation denied men the opportunity to enter this domain. Despite their growing representation, they are still a minority in nursing in countries across the globe. When the occupational roles do not conform to the gender-appropriate roles prescribed by the society, the 'male' nurses' prestige and self-esteem are at risk since others recognize them neither as true nurses nor as real men. Drawing majorly from secondary sources and data gathered from an anthropological study of in-home care providers in the South Indian state of Kerala, this paper on the predicament of men in nursing throws light on the 'spoiled identity' they carry; the work stress, gender stereotyping, stigma and discrimination they encounter by always being suspected and their very identity and sexual orientation questioned. A note on the strategies employed by them to overcome the problems is also within the purview of this paper.
\end{abstract}

Keywords: nursing, profession, male nurses, care providers, identity 


\title{
En Busca de una Identidad: Analizando el Caso de los Proveedores de Cuidados de Salud Masculinos
}

\author{
Anakha Ajith \\ University of Hyderabad
}

\section{Resumen}

Al ser este un trabajo realizado principalmente por mujeres, la enfermería ha olvidado el lugar de los hombres dentro de la profesión a pesar de su contribución desde tiempos inmemoriales. Los intensos esfuerzos de Florence Nightingale para transformar la enfermería en una ocupación femenina respetable le negó a los hombres la oportunidad de ingresar a este campo. Aunque el número de hombres que ingresan a la profesión ha aumentado con los años, todavía se mantienen como una minoría en el campo de enfermería en países de todo el mundo. Cuando los roles ocupacionales no se ajustan a los roles apropiados para el género prescritos por la sociedad, el prestigio y la autoestima de los estos enfermeros se encuentran en riesgo ya que otros no los reconocen como verdaderos enfermeros ni como verdaderos hombres. Basándose principalmente en fuentes y datos secundarios recopilados de un estudio antropológico de proveedores de atención domiciliaria en el estado de Kerala, en el sur de India, este documento sobre la situación de los hombres en el campo de enfermería arroja luz sobre la "deteriorada identidad" que llevan consigo; el estrés laboral, los estereotipos de género, el estigma y la discriminación que enfrentan al ser siempre sospechosos y su identidad y orientación sexual cuestionadas. También se encuentra una nota sobre las estrategias empleadas por ellos para superar los problemas dentro del ámbito de este documento.

Palabras clave: enfermería, profesión, enfermeras, proveedor de cuidados, identidad 


\section{Ajith - In the Pursuit of an Identity}

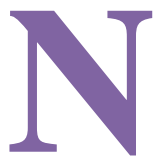

ursing, perceived to be a profession meant for women then and now, is a field that largely retains the characteristic of female domination across the globe. Any discussion on the profession of nursing would remain incomplete without a mention of the efforts of Florence Nightingale whose brainchild was to transform nursing into a respectable female occupation. When feminine qualities found parallels with attributes of a nurse, doors to enter the profession were closed for men. Women who are naturally considered as caregivers became the suitable members to perform the role of nurses thereby rendering nursing the tag of a more or less single-sex occupation. Landivar (2013) identified an ascent in the number of males in the US registered nurse force since the 1970s, yet they remained a modest 11 percent in 2011 (as cited in Cottingham, 2019, p.198). Purnell (2007) demonstrated a worldwide point of view where men comprise less than $10 \%$ of the nursing workforce in China, Denmark, Finland, Hungary, Australia, Mexico, and New Zealand. Few men seemed to become nurses in Pakistan and Arab Middle-Eastern countries. Italy, Spain, and Portugal had about $20 \%$ of men as nurses when England and Israel had slightly fewer men in the profession. Male nurses in the Czech Republic and Francophone Africa displayed greater numbers and men outnumbered women in the latter. Bernabeu-Mestre, Carrillo-García, Galiana-Sánchez, García-Paramio, \& Trescastro-López (2013) find that "women represent more than $80 \%$ of nursing professionals in Spain” (p. 288). Ayala, Holmqvist, Messing, \& Browne (2014) report that only 6-10 percent of nurses in Chile are men, according to 2013 statistics available (p.1481). Aspiazu (2017) states that "in 2016, 85\% of nurses in Argentina were women" (p.11).

These numbers do not lie. However, contrary to what is imagined, Mackintosh (1997) claims that "men's contribution has been perceived as negligible due to the 19th-century female nursing movement has had on the occupation's historical ideology" (p.232). The historical backdrop of nursing has more or less entirely neglected the role of men despite their involvement as caregivers in asylums, army, etc. Many scholars have similar findings:

Men have played a dominant role in organized nursing dating back to 330 A.D. in the Byzantine Empire. During this era, hospitals were one of the major institutions where nursing emerged as a separate occupation, primarily for 
men (Bullough, 1994). Moreover, military, religious, and lay orders of men known as nurses have a long history of caring for the sick and injured during the Crusades in the 11th century (MacPhail, 1996). In the United States, men served as nurses during the Civil War. John Simon, the lesser-known rival of Florence Nightingale, was the founder of an experimental field hospital in Germany during the Franco-Prussian War (1870-1871). Male nurses were hired to staff the hospital, and mortality rates among the troops were kept abnormally low (Halloran \& Welton, 1994). (Meadus, 2000, p.6)

These works attempted to highlight that nursing is not a field alien to men though women have established kind of a monopoly over it since the last few centuries. In the mid- $20^{\text {th }}$ century, nursing witnessed a drastic change in the gender composition of its workforce. The research by Ramacciotti and Valobra (2017) and Ramacciotti (2020) reveal that the history of nursing in Argentina saw a state-sponsored feminization of the profession. The efforts of the Eva Perón Foundation in this direction are mentioned by the authors. They point out that "the nursing schools reinforced this discourse that accentuated the feminization process and made the role of males invisible" (Ramacciotti \& Valobra, 2017, p.382). Though male entry was restricted by several nursing schools, it was not uniform. The authors provided instances of nursing schools that did not discriminate against men. The Red Cross School of Nurses in Santa Fe, the Ministry of Health of the Province of Buenos Aires' school for paratroopers, etc. were among them. "The 1944 San Juan earthquake in Argentina is also considered a landmark event that attracted many women to join nursing" (Ramacciotti, 2020, p.48). Ramacciotti does not forget to mention how female pioneers in healthcare in the country (who were influenced by the system created by Florence Nightingale) found nursing an ideal occupation for women. "Cecilia Grierson's efforts to professionalize nursing seem to have resulted in its feminization" (Ramacciotti, 2020, p.62). Studies also demonstrate the association of gender and caregiving, and the tendency to replicate the sexual division of labor in the private sphere into the public sphere. Gill (2018) identifies this "gendered construction of the occupational realms" in the Indian context (p.44). Ramacciotti (2020) also shares a similar view when she says "women occupied jobs in which they 


\section{Ajith - In the Pursuit of an Identity}

displayed that supposed feminine nature" since they were efficient in those tasks (p.36).

It is also true that nursing as a profession does not enjoy a great status; nurses' subservient position compared to doctors is particularly remarkable. Nurses were considered as lacking in skill and there had been a dishonour attached to nursing prevalent in the country. Nurses have many times been questioned of their character since they involve in intimate body-care, interact with men, work during night hours, and deal with polluting substances (Abraham 2004; French, Watters \& Matthews, 1994; Hollup, 2014; Nair \& Healey 2008; Percot 2006; Varghese \& Rajan 2011). Authors like Etzioni (1969) have classified nursing in the category of semi-professions, along with teaching and social work. Yet, nursing had not received due respect until recently in a developing country like India (Gill, 2018).

A transformation in this scenario began to occur due to globalization and the increased demand for nurses overseas. Indian nurses who have been migrating internationally witnessed respect for their profession and improved working conditions which paved way for their economic security (George 2005; Nair \& Healey, 2008; Percot 2006). Even though the major motive behind migrating was financial independence, overseas migration not only helped the nurses fetch themselves enhanced earnings but also became the reason for many to select nursing as a vocation back in their homeland. More nurses became sought after in the marriage market and a preference for nurses working abroad was observed (Percot, 2006a).

The better prospects that migration offered were able to attract a lot of men to enter the field and various studies reported an upsurge in nursing becoming a career alternative for men in the last few decades (Buerhaus, Staiger, \& Auerbach 2004; Hodges et al., 2017; Trossman, 2003; Walton-Roberts, 2010; Zamanzadeh et al., 2013). However, they are still negligible and a nation-wide analysis of the nursing institutions in many countries would testify this. Predominantly, female occupations are thought to be less professional compared to male-dominated ones and various scholars adhere to the fact that gender acts as an obstacle to professional advancement. Gilbert and Rossman (1992) opine that this happens since "women are viewed from a gender perspective as less able to take on leadership roles" (p.234). The situations of 
men who go into female- concentrated professions have to be looked at from various angles. This paper majorly focuses on the difficulties, as well as benefits the 'male' nurses experience due to being in this field. The gender bias and discrimination 'male' nurses are subjected to for doing the 'women's work' has also been highlighted.

\section{The Two Conjectures About Male Nurses and The Issue of Identity}

Certain professions are considered appropriate for women, the oft-cited ones among these being teaching and nursing. Meanwhile, women had not limited themselves and remained restricted to those realms that are thought to be apt for them. They have been entering previously male-dominated professions and have become doctors, lawyers, and businesswomen. Though their journeys were hard, many scholars opine that women received much more support and encouragement compared to men who enter female-concentrated jobs like nursing. The belief that nursing is an arena meant for women remained even after men re-entered the vocation, thereby leading Mackintosh (1997) to produce the assumptions "that the introduction of male nurses was an attempt in some way to violate the respectability of the occupation and male nurses could therefore not be "real" men since men were not naturally capable of performing caring activities" (p.235).

These two conjectures have to be analyzed critically since these statements are a threat to the identity of the male nurses in particular and men in general. Since a profession is seen naturally suitable for a particular gender it does not mean that the entry of another gender into it would make it less respectable or irreverent.

\section{Men's Entry: Boon or Bane?}

The world has been witnessing the interplay between gender and division of labor due to which occupational sex-typing prevails. Elliot (2016) suggests that "the central features of caring masculinities are their rejection of domination and their integration of values of care, such as positive emotion, 


\section{Ajith - In the Pursuit of an Identity}

interdependence, and relationality into masculine identities" (p.241). In a system where men are favoured, those occupations labelled traditionally male have had an upper hand. Evans (1997) proposes that "in female-dominated occupations such as nursing, patriarchal gender relations function and due to this male nurses tend towards powerful and authoritarian positions" (p.226).

A few authors have found that nursing has been a profitable game for men who chose it as a career. Lupton (2006) identifies three main phenomena and writes that:

Firstly, men progress more quickly than women to senior positions - riding the 'glass escalator' (Williams, 1995). Secondly, men may be channelled into particular specialities in occupations that are regarded (by themselves and by others) as more appropriate to their gender, and that often carry greater rewards and prestige-which may be both a cause and a consequence of their gender associations. The third advantage relates to remuneration. Williams (1995) and England and Herbert (1993) have shown that men are paid more than women in female-concentrated occupations. (pp.105-106)

Though men have had these obvious advantages concerning remuneration and placement in elite/ superior positions, many difficulties are involved in the process. Heikes (1991) puts forth the idea that:

Male nurses, like other tokens, experience stress at work due to their token status and tend to experience conflict in the work setting because of incompatible gender socialization. The very traits which help males in other occupations- ambition, assertiveness, and strength-create stress and friction for the male which may hinder them occupationally. In addition to workrelated stressors, they must cope daily with the consequences of being a man doing "women's work". (p.398)

"Cockburn has suggested that the handful of men who cross into traditional female areas of work at the female level will be written off as effeminate, tolerated as eccentrics or failures. (1988, p. 40)" (as cited in Lupton, 2006, p.106). Simpson (2004) studied masculinity at work and noted that "emotional labour such as teaching, nursing, and social work may call for special abilities that only women are deemed to possess (Hochschild, 1983)". This can "invite challenges to men's sexuality and masculinity if they adopt a more feminine approach" (Simpson, 2004, p.7) 
Another well-documented theme is that of role strain ${ }^{1}$. Stott (2004) identifies that "males tended to choose "less intimate" specialization areas such as administration, anesthetics, and psychiatric nursing to cope with role strain in a female-dominated profession. (p.92). She also comments that "the male nurses perceived themselves as being the victims of discrimination" (p.92). "Issues such as role strain, minority status, and stereotypical attitudes are perceived as being central to the unique conflicts facing men in nursing". (Stott, 2004, p.95)

\section{Do Men Get Support to Enter Female-Concentrated Professions?}

According to Egeland and Brown (1988), "males appear to encounter more negative criticism from the public on entering female-identified occupations. For example, they are "held suspect" and penalized for role violation" (as cited in Meadus, 2000, p.6). These men encounter a lot of hardships and are subjected to criticism and ridicule since they challenge the conventional image that nursing has (Villeneuve, 1994; Williams, 1992). Meadus (2000) notes that "another commonly held stereotype concerning men who choose nursing as a career is that they are effeminate or gay (Boughn, 1994; Gray et al., 1996; Williams, 1992; Williams, 1995)" (p.8). "The stigma associated with homosexuality exposes male nurses to homophobia in the workplace". (Harding, 2007, p.636). In the opinion of Mangan (1994), the labelling of male nurses as effeminate or homosexual can be interpreted as a social control mechanism that redefines nursing as a woman's work" (as cited in Meadus, 2000, p.9). Segal (1962) elucidates that "male nurses are suspect because they enter a traditionally female occupation. They are involved in a status contradiction between characteristics ascribed to men in our society and characteristics that are supposed to inhere among members of the nursing profession" (p.37).

Since the perception that female-oriented jobs are easy to perform exists, many a time the male nurses are regarded as lacking skills to perform maleoriented professions. They are also categorized as lazy by some since they choose female-dominated jobs that demand less effort and physical strength. 


\section{Ajith - In the Pursuit of an Identity}

Citing Macintosh (1997), Anthony (2004) asserts that "when the nursing profession perpetuates the feminine stereotype and uncritically uses a feminine language and value system, individuals who do not fit that stereotype are at risk for being oppressed and silenced by those who do fit the image" (p.123). It is not just in the workplace that male nurses encounter these difficulties and suffering. During their education as well, male students are likely to suffer from these issues and barriers such as "the feminine paradigm in nursing education, a lack of role models and isolation, gender-biased language, differential treatment, different styles of communication, and issues of touch and caring" (O'Lynn, 2007, p.174).

It has been accentuated by Evans (1997) that male nurses employ "strategies that allow them to distance themselves from female colleagues and the quintessential feminine image of nursing itself, as a prerequisite to elevating their prestige and power" (p.226). The gender-specific specializations whereby male nurses are involved in selecting the more 'masculine' elements have been analyzed already. Such specialties include psychiatry, anaesthesiology, emergency care, etc.

\section{Significance of the Study}

As far as the Indian scenario is concerned, the literature suggests that the country has produced umpteen nurses and has been a supplier of nursing care services worldwide. The greater part of these studies on nursing has had hospital-based nursing as the focus. A handful of entries has looked at homebased nursing care as research conducted in India has mainly concentrated on nursing homes, community nursing, and palliative care. Indian nurses have migrated internationally and a lion's share of them have been nurses from Kerala, "the leading Indian state for the training and 'export' of nurses for the international market” (Walton Roberts \& Rajan, 2013, Introduction, para 3). 'Home nursing' (home-based nursing) has become a buzzword in the arena of nursing care in Kerala over the last few decades. The care providers stay with the patients in the latter's homes and deliver their caregiving services. Though some studies like the one by George and Bhatti (2019) have focused on male nurses who work in hospitals in Kerala, there has been no scholarly effort to 
look into the cases of men who work as in-home care providers. The need for in-depth studies on home-based care and live-in care providers prompted the researcher to undertake the study with the aid of an anthropological perspective and methodology.

\section{Methodology}

The data for the study were collected from May 2018 to July 2019 from three categories of people who formed the part of the study viz. the care providers, owners of nursing agencies who supply the care providers, and customers who avail the services to take care of patients. The area chosen for the study was the districts from Southern Kerala where the home-based care industry is more in prevalence. Thiruvananthapuram, Kollam, Pathanamthitta, Alappuzha, Kottayam, and Ernakulam were these districts. In-depth interviews of the respondents with the aid of a semi-structured schedule were conducted. The face-to-face interviews lasted for 55 minutes on average. The nursing agencies which the participants were associated with served as the sampling frame. Since the number of men working for an agency is less, the snowball technique had to be applied to reach a desirable sample size.

The data presented in this paper consider the cases of 20 male care providers who were a part of the study that had a total sample of 150 care providers. The interviews were conducted in the regional language (Malayalam) and were not tape-recorded. The anonymity of the respondents was assured and their informed consent sought. The interview schedule initially framed in English was later translated to Malayalam for convenience. The respondents were asked questions about their reasons and motivations behind taking up the job, their prior work experiences, their relationship with the patients, and the pros and cons of this non-traditional occupational choice. They were also asked to briefly narrate their experiences in the field. 


\section{Results}

\section{Previous Employment and Prior Work Experiences}

The twenty men were aged between 32 and $70(M=48.05$ years, $S D=11.44)$. Their experience in the job ranged from a few years to about two decades $(M$ $=7.7$ years, $S D=4.76$ ). Though only four of the men were academic nursing qualified, five others have had prior experience as hospital staff like nursing attendants and aides. Low pay and difficult working conditions were the two main reasons why these people left hospital-based work. 55 percent of the sample has taken nursing training from the private nursing agencies that they are associated with. The nursing trained participants also include five people who were trained under the Indian Red Cross Society and thus guided by hospital nurses. Most of the respondents perform health care tasks like insulin administration, monitoring blood pressure, catheter care, nasogastric tube feeding, etc.

\section{Reasons for Becoming a Male Caregiver}

An inquiry into the rationale for taking up the job revealed that eight men were influenced by their relatives and friends. The wives of four out of these eight people also worked as in-home care providers and were the ones who motivated their spouses to take up the job. When four participants opined that they found the job satisfying and rewarding, five people expressed a desire to help people since they considered serving the sick as a divine activity. Nine participants mentioned that this job paid them better than their previous occupations. For them, better pay has been a motivating factor in addition to the interest they had to take care of patients. However, it could be known that this was never a first-choice occupation for any of the study participants.

Thomas recalls, "My wife has been working in the field since 2007 and she persuaded me to join the same nursing agency she was working for. After I got in, I realized that I love to care for the elderly. I am not in this job just to earn money; I want to make a change in the lives of people. My previous job used to pay me better but here I find myself more satisfied when I serve the 
ailing and needy. I think I should thank my wife for leading me to this job'. John discerns, 'It needs a lot of patience and will power to be in the profession of nursing. It is never an easy job for men to do this since we have not done the caring work at our homes. But one thing for sure is that caring for the sick is a divine activity. My parents are happy about the good work I am doing by helping those in need. It was my elder sister (a hospital nurse) who, from my school days, has inspired me by telling the stories of nurses who did the caring when doctors did the curing. But nursing was not my first choice of occupation. When I wanted a change from my previous job, I thought why not give home-based care a try. And here I am'.

\section{Perceptions About Nursing and Caregivers}

Out of the 20 participants, six either considered caregiving as a women's job or thought it is perceived so by society. The rest voiced the idea that they were comfortable working in a female-dominated sector and that men are also equally capable of providing care to the ailing. Some respondents believe that as long as they look after male patients alone, there is nothing to feel ashamed about. Nevertheless, only a quarter of the participants have revealed their occupational identity to all of their relatives and friends. When 12 men made their family members aware of their job, three kept it hidden even from their close kin. Out of these 17 who let their family members informed about the job, six said that their family members were very supportive. The rest pointed out that their families had mixed opinions about them doing the job. A major reason why men had to hide their work identity was to not disclose their involvement in home-based work. They were afraid of the humiliation they might have to suffer if their relatives and friends know that they are doing 'women's work'. It is this fear that led 14 of the participants to disguise themselves to be working as hotel cooks, shopkeepers, security personnel, and teachers. Most of them worked in other districts and did not like to work near their hometowns. This confirms the fact that many men often do not get enough social support to perform their roles as care providers. 


\section{Ajith - In the Pursuit of an Identity}

When they were criticized and ridiculed for their choice of job, some care providers sought solace in the words of their male co-workers, and relatives who performed similar work. Michael states, 'I am not alone, my brother-inlaw also works as a home-based caregiver. I also have a few friends who do the same job. I used to be a nurse at a private hospital. I left the job since I had difficulties with the work conditions. Later, I went abroad in search of a better life but I had to return to Kerala due to personal reasons. After a couple of years, I took up this job. Even if others believe that this is a small job, for me it is a big deal. It is this job that fetches my bread and butter now and I am well pleased with it'. Harry, who dropped his job as a hospital nurse also has a comparable opinion and thus says, 'my uncle and friends who are home nurses have been my support system. Even when my wife's family asked me to quit the job and find another one, they stood by me and supported my decision to continue in the job'. Some men in the study had to choose the job at the cost of losing their prestige. In such cases, the desire to help people and work satisfaction were the pull factors (besides better pay than the previous job).

\section{Problems Facing Male Caregivers}

Five men recalled instances of physical or mental harassment they had experienced from the patient/ patient's relatives. It was mostly the patients who physically assaulted their care providers out of their anger and frustration. But the caregivers understand the helpless conditions of the patients and adjust with them. Three participants pointed out how the labels of 'gay men'/ 'homosexual' haunt the men in the caregiving profession and one respondent recollected an incident where he was approached by a patient's relative since he was mistaken for a gay man.

The participants were asked if their gender restricted them from performing their roles as care providers. Though some of them believe that the provision of care is women's job and thus the work performed by male care providers are stigmatized, eight men stated that it does not matter since they do not take care of patients of the opposite sex. A few reinstated that the job still lacks respect in our society. However, none of the respondents opined 
that they find any aspect of their work polluting- whether it be bathing or toileting the patient. It is also worth noting that none of them expressed dissatisfaction with the job though they have various inconsequential difficulties due to staying away from their families.

There still prevails a stigma around nursing and the study participants reveal that it is worse when it comes to home-based nursing. Men who perform non-traditional occupations could have a sense of shame when they do not live up to social expectations. Adam comments, 'People think that we are unqualified and good for nothing since we are in-home care providers. This makes me sad because many people like me are trained in healthcare tasks. I have not disclosed my occupational identity to my relatives since they believe it is unmanly to involve in home-based care work. They will tell you that men are meant to work outside homes and not inside.' John also has a similar opinion on the societal perception of home-based caregivers. He says that 'Some people have asked me why I go for a job where I have to clean people's dirt and fecal matter. I was told that it's better to work in a tea shop or a hotel'. John hypothesizes that even if nurses are academically qualified personnel, they are equated to servants or cleaning staff. He laments that society doesn't recognize the good work caregivers are doing. Jacob mentions that 'Not just women, but men in this field are also prone to harassment and moral policing. We men are considered as homosexuals. People call us 'Chanthupottu' (A term which became popular in Kerala after a Malayalam movie of the same name and is used by some people in the state to refer to homosexual or effeminate type men). Even now, caregiving does not have a good reputation in our society'. George finds that 'Men in this job find it difficult to get marriage alliances. A male home nurse is often portrayed as a gay man'. He also adds that 'Our society perceives that being homebound is not something meant for men and it is due to this reason that most of us do not reveal our job identities. I'd rather like to work as a hospital nurse; I think that has a better acceptance in our society.'

\section{Relationship with Patients and Work Satisfaction}


When their family members and relatives did not take proper care of elderly patients (due to various reasons), paid care providers came to their rescue. They have been a tower of strength for the sick elderly as they sustain the lives of the patients by providing emotional support in addition to physical tending. Francis describes, 'It feels good to be in this job since there is a homely atmosphere in the patient's house. I take care of an 87-year- old man who broke his leg recently. I don't know how long he will survive. I consider him like my grandfather. His children are busy with work and they do not spend enough time with him. He enjoys my company and I often crack jokes to make him laugh. I feel happy when I see him smile'. Vijay is of the view that one has to be a good listener when involved in elderly patient care. He says, 'Many times the adult children do not have time to listen to what their elderly parents have to say. Then, it is the care providers who have to lend their ears to the stories of elderly patients. This will help develop bonding and attachment between the two and might also help improve the health condition of the patient'.

\section{Strategies Employed to Sustain in the Field}

In India, even if they enter female-dominated occupations, the majority of men try to make sure that they conform to the mainstream / traditional masculine values. This is in contrast to the study undertaken by BodoquePuerta et al. (2019) in Spain which found that the male social caregivers "distance themselves from the values of traditional masculinity to construct an alternative masculinity" (p.220). It was observed that the male care providers consider knowledge to perform physiotherapy as something that would give them an upper hand compared to their female counterparts.

The study participants consider being able to perform physiotherapy as a desirable qualification for male care providers. 12 out of the 20 participants have done physiotherapy courses and 5 men have learned the basics of the same through experience in the field over the years. This aspect is akin to male nurses concentrating on specializations like psychiatric nursing that appears to be a specialty that helps them display their masculine qualities. Most of the 
participants also mentioned that they do not involve in performing any household tasks at the patient's home unless they work for elderly patients who do not have any co-resident relatives. This is in contrast to the female care providers who often help with the household chores though they are employed for patient's healthcare. The respondents highlighted the fact that they see to it that they maintain the 'clean habits' like abstaining from alcohol consumption and smoking since these are considered pre-requisites to enter the field and remain in the job.

\section{Does a Glass Escalator Exist?}

A feature of 'glass escalator' (Williams, 1992) that is observed in this study is the gender-wage gap. Female care providers formed the majority of the larger study. Compared to them, the male care providers earned about 2000 rupees more. The average monthly salary of the men is around 16000 rupees $(\sim 225$ USD) and thus approximately 15-20 percent more than that of women. According to the nursing agency owners, this wage gap exists because taking care of male patients is riskier and more difficult. When asked about their opinion on the wage gap and why they thought men out-earned women, half of the respondents felt that since it happens in other jobs, the same is replicated in this job too. The other half believed that they are paid more as it is tougher to take care of male patients and therefore to retain male care providers in the job, they should have better pay than their female co-workers. Despite this being the case, most of the respondents mentioned that their work is harder than that of their female colleagues.

It could also be noticed that when choosing an employee, clients were particular about habits such as smoking and alcohol consumption of male care providers. They do not wish to employ men who could be a threat to the safety of the female family members. John remarks, 'I do not consume alcohol or smoke cigars. I have always behaved well with everyone I have worked for. I think teetotallers are better liked by patients' families. Though this is the case, bachelors like me find it difficult to make it into this field because we are held suspect for various reasons'. Unlike hospital-based nurses, in-home care 


\section{Ajith - In the Pursuit of an Identity}

providers do not have any benefits and job promotions/ advancements in their positions. Since the employees carry the same job title irrespective of gender, it cannot be completely categorized as an instance of a glass escalator. Moreover, some of the above narratives demonstrate the difficulty that men (especially, unmarried men) experience to gain entry to the field and to sustain in it. As male care providers are employed only for patients of the same gender, they do not pose a threat to the opportunities of the womenfolk.

\section{Discussion}

This study complements the prior research on men in nursing by considering the cases of a few men in home-based care services from the state of Kerala in South India. The efforts of male nurses towards the profession have not been adequately recognized though they have been actively involved in caring and nursing people. Due to scrutiny and suspicion that arise when men enter nursing, several men identified a split in terms of how they presented themselves at work and outside work. Some do not like to be known as nurses when they are in the social context since their tags as 'male' nurses often go against the desirable notions. It is also worth noting that a non-gendered occupational title can have a positive effect on societal perceptions. "In Mauritius, the professional title and grade 'nursing officer' is non-gendered and thus does not represent a barrier to men" (Hollup, 2014, p.758). On the contrary, some of the study participants from Kerala consider the term 'home nurse' to suit female caregivers more than males.

Studies have reflected that while most men expressed higher levels of satisfaction with their career, role strain is inescapable. Participants in the present study also expressed similar views and tensions related to the public perceptions of men performing caring work and the indifferent attitudes of people around them. But they believe that as long as they look after male patients alone, there is nothing to feel ashamed about. They also highlight the fact they work as per the care plan and do not cross the boundaries to help their clients in domestic chores (unlike the female caregivers who go the extra mile). In their study on male nurses from Kerala, George and Bhatti (2019) find that "nursing is not perceived suitable for men and the majority of the 
participants complained about the difficulties in convincing their families or being ridiculed by their friends" (p.121). The respondents of the current study had similar opinions though not all of them consider the job as women's forte. However, it sheds light on men performing home-based care being prone to double stigma: for taking up nursing, a women's job and for working at home, a sphere meant for women. Likewise, Acker (1990) highlighted the gendering of occupations and workplaces (cited by Scrinzi, 2010, p.46).

Prior research on men in nursing highlighted men's choice of specialism and its association with career progression. Male caregivers in Kerala also showed an interest in one special area- the ability to perform physiotherapy and they take pride in being able to perform the task. However, this does not contribute to career progression. An effort made to analyze the presence of a glass escalator as experienced by the study participants shows that there are no real 'hidden advantages' (Williams, 1992) that they have over female caregivers.

It was observed that support from significant others was a persuasive factor in occupational selection. Zamanzadeh et al. (2013) came up with parallel findings from their study of male nurses and the authors add that "most of this support comes from females who are close to men that are interested in pursuing a nursing profession" (p.53) This has been true to an extent in the current study. However, unlike their study that found career opportunities and salary as the most important motivators for entrance (Zamanzadeh et al., 2013, p.53), this study shows that desire to help people and satisfaction derived from the job have also been more important motivators for the male nurses. According to Araüna et al. (2018), the ability to use and maintain a sense of humor in critical situations has been identified as a characteristic of male nurses. The caregivers in the study also exhibited similar conduct. Dill et al. (2016) in an analysis of a 'wage penalty' find that "men who are involved in direct care work occupations experience a penalty for caring" (p.354). However, the participants in the present study do not perceive the existence of such a penalty. The narratives provided above exemplify that the wages they earn are satisfactory and a considerable proportion of the sample find it better compared to that of their previous occupations. 


\section{Conclusion}

The paper aimed to analyze male in-home care providers' reasons and motivations behind taking up the job, their prior work experiences, their relationship with the clients/ patients, and the perceived pros and cons of this non-traditional occupational choice. The study from the Indian state had male caregivers comprising only $13.33 \%$ of the total sample. The situation is not different in other states of the country. It is identified that home-based care is also female-concentrated, akin to hospital-based nursing. Authors like Ayala et al. (2014) consider the entry of men in substantial numbers to benefit the future of nursing as they assume that "the masculine presence could counterbalance an alleged lack of political power" (p.1483). But, the authors caution that this move "may lead to the reproduction of earlier historical inequalities if not handled judiciously" (Ayala et al., 2014, p.1484). Although Shen-Miller and Smiler (2015) opine the possibility of an overall rise in wages in the field as a result of men's substantial entry, a remark is also made about a subsequent gender-wage gap that could occur (p.272). In a similar line, Bernabeu-Mestre et al. (2013) opine that the inclusion of more men into nursing should not be at the cost of compromising equality in terms of responsibility and power (p. 288). However, the current study participants do not reflect the presence of a glass escalator, barring the aspect of the genderwage gap.

As several authors consider male (re)entry to nursing as a much welcome move, multiple interpretations have come up from various studies that were conducted globally. "The presence of men in feminized occupations can challenge the sex-typing that characterize them" (Scrinzi, 2010, p.59). "It is anticipated that a large influx of men will raise the profession's status and prestige" (Evans, 1997, p.227). Elliott (2015) mentions the need to encourage men to engage in gender-equal and caring practices. (p. 247). Research by Aranda et al. (2015, p. 105) comes up with similar findings and argues that the inclusion of men "could produce a change in gender stereotypes". Dill et al. (2016) are also optimistic that "the presence of men in low- and middleskill care work occupations may redefine "women's work" as both men's and women's work" (p.355). 
As Mackintosh (1997) rightly puts forward, "the contribution men have made to nursing history should be recognized more positively, thereby allowing male nurses the opportunity to fulfill their roles with full knowledge of their place in the historical background of the profession" (p.236). The present study also is in favor of bringing a change to the 'feminization of nursing' (O'Lynn, 2007) and thereby help men reinforce their caring identities. It also finds that caregiving becoming a gender-neutral activity as an after-effect of the enlarged representation of male caregivers is a possibility that cannot be ignored. Though the sample size of the study is limited, it is envisioned that the study would pave the way for future research and can be replicated in other parts of the country.

\section{Ethical Approval}

The study on home-based caregivers from Kerala was approved by the University of Hyderabad. The Institutional Ethics Committee's certificate to conduct the research was granted on 09/03/2018 for the Application No. $\mathrm{UH} / \mathrm{IEC} / 2018 / 6$.

\section{Notes}

${ }^{1}$ Role strain is "when an individual is likely to experience tension in coping with the requirements of incompatible roles" (Jary, D., \& Jary, J., 1991, p. 538)

\section{Acknowledgements}

The author thanks Prof. BV Sharma, Dr. Aparna Ajith, Dr. Alok Pandey, Yesudas Thomas, and the anonymous reviewers for their constructive comments on the manuscript. 
330 Ajith - In the Pursuit of an Identity

\section{References}

Abraham, B. (2004). Women nurses and the notion of their 'Empowerment', Discussion Paper No 88, Kerala Research Programme on Local Level Development, Centre for Development Studies, Thiruvananthapuram. Anthony, A. S. (2004). Gender bias and discrimination in nursing education: can we change it? Nurse Educator, 29(3), 121-125.

https://doi.org/10.1097/00006223-200405000-00011

Aranda, M., Castillo-Mayén, M. D. R., \& Montes-Berges, B. (2015). Has Changed the Traditional Social Perception on Nurses? Attribution of Stereotypes and Gender Roles. Acción Psicológica, 12(1), 103-112. https://doi.org/10.5944/ap.12.1.14353

Araüna, N., Tortajada, I., \& Willem, C. (2018). Portrayals of caring masculinities in fiction film: The male caregiver in Still Mine, Intouchables and Nebraska. Masculinities and Social Change, 7(1), 82102. https://doi.org/10.17583/MCS.2018.2749

Aspiazu, E. (2017). Las condiciones laborales de las y los enfermeros en Argentina: entre la profesionalización y la precariedad del cuidado en la salud. Trabajo y Sociedad, 28. 11-35.

https://ri.conicet.gov.ar/handle/11336/71306

Auster, D. (1979). Sex differences in attitudes towards nursing education. Journal of Nursing Education, 18(6), 19-28.

Ayala, R. A., Holmqvist, M. T., Messing, H. B., \& Browne, R. F. (2014). Blessed art thou among women: Male nursing students and gender inequalities in Chile. Nurse Education Today, 34(12), 1480-1484. https://doi.org/10.1016/j.nedt.2014.04.022

Barkley, T. W., \& Kohler, P. A. (1992). Is nursing's image a deterrent to recruiting men into the profession? Male high school students respond. Nursing Forum, 27(2), 9-14.

https://doi.org/10.1111/j.1744-6198.1992.tb00906.x

Bodoque-Puerta, Y., Comas-d'Argemir, D., \& Roca- Escoda, M. (2019). 'What I Really Want Is a Job'. Male Workers in the Social Care Sector. Masculinities and Social Change, 9(2), 207-234.

https://doi.org/10.17583/MCS.2020.4827 
Bernabeu-Mestre, J., Carrillo-García, C., Galiana-Sánchez, M. E., GarcíaParamio, P., \& Trescastro-López, E. M. (2013). Género y profesión en la evolución histórica de la Enfermería Comunitaria en España [Gender and profession in the historical development of community nursing in Spain]. Enfermeria clinica, 23(6), 284-289.

https://doi.org/10.1016/j.enfcli.2013.07.005

Buerhaus, P. I., Staiger, D. O., \& Auerbach, D. I. (2004). New signs of a strengthening U.S. nurse labor market? Health Affairs, 23(Suppl1), W4 526-W4 533.

https://doi.org/10.1377/hlthaff.w4.526

Bullough, V.L. (1994). Men, women, and nursing history. Journal of Professional Nursing, 10(3), 127. https://doi.org/10.1016/8755-7223(94)90002-7

Boughn, S. (1994). Why do men choose Nursing? Nursing and Health Care, $25,406-411$.

Cockburn, C. (1988). The gendering of jobs. In Walby, S. (Ed.), Gender segregation at work (pp. 29-42). Milton Keynes: Open University Press.

Cottingham, M. D. (2019). The missing and needed male nurse: Discursive hybridization in professional nursing texts. Gender, Work \& Organization, 26(2), 197-213. https://doi.org/10.1111/gwao.12333

Cummings, S. (1995). Attila The Hun Versus Attila the Hen: Gender socialization of the American nurse. Nursing Administration Quarterly, 19(2), 19-29.

https://doi.org/10.1097/00006216-199501920-00006

Dill, J. S., Price-Glynn, K., \& Rakovski, C. (2016). Does the "Glass escalator" compensate for the devaluation of care work occupations? Gender \& Society, 30(2), 334-360. https://doi.org/10.1177/0891243215624656

Egeland, J.W., \& Brown, J.S. (1988). Sex role stereotyping and role strain of male registered nurses. Research in Nursing and Health, 11(4), 257-267. https://doi.org/10.1002/nur.4770110407

Elliot, K. (2016). Caring masculinities: Theorizing an emerging concept. Men and Masculinities, 19(3), 240-259. 


\section{https://doi.org/10.1177/1097184X15576203}

England, P., \& Herbert, M.S. (1993). The pay of men in 'female' occupations: Is comparable worth only for women? In Williams, C.L. (Ed.), Doing 'Women's Work': Men in nontraditional occupations (pp. 28-48). London: Sage.

Evans, J. (1997). Men in nursing: Issues of gender segregation and hidden advantage. Journal of Advanced Nursing, 26(2), 226-231. https://doi.org/10.1046/j.1365-2648.1997.1997026226.x

Fisher, M. (1999). Sex role characteristics of males in nursing. Contemporary Nurse, 8(3), 65-71. https://doi.org/10.5172/conu.1999.8.3.65

Floge, L., \& Merrill, D. (1986). Tokenism reconsidered: Male nurses and female physicians in a hospital setting. Social Forces, 64(4), 925-947. https://doi.org/10.2307/2578787

French, S., Watters, D., \& Matthews, D. (1994). Nursing as a career choice for women in Pakistan. Journal of Advanced Nursing, 19(1), 140-151. https://doi.org/10.1111/j.1365-2648.1994.tb01062.x

George, C., \& Bhatti, F. (2019). The Voices of Male Nurses in Kerala:

Career Choice and Satisfaction. Space and Culture, India, 7(3), 115-126. https://doi.org/10.20896/saci.v7i3.492

George, S. M. (2005). When women come first: Gender and class in transnational migration. Berkeley: University of California Press Gilbert, L. A., \& Rossman, K. M. (1992). Gender and the mentoring process for women: Implications for professional development. Professional Psychology: Research and Practice, 23(3), 233-238.

https://doi.org/10.1037/0735-7028.23.3.233

Gill, R. (2018). Gender Stereotypes: A History of Nursing in India. Social Action, 68, 43-55.

Gray, B. (2010). Emotional labour, gender and professional stereotypes of emotional and physical contact, and personal perspectives on the emotional labour of nursing. Journal of Gender Studies, 19(4), 349-360. https://doi.org/10.1080/09589236.2010.514207

Gray, D.P., Kramer, M., Minick, P., McGehee, L., Thomas, D., \& Greiner, D. (1996). Heterosexism in nursing education. Journal of Nursing Education, 35(5), 204-210. 
Harding, T. (2007). The construction of men who are nurses as gay. Journal of Advanced Nursing, 60(6), 636-644.

https://doi.org/10.1111/j.1365-2648.2007.04447.x

Heikes, E.J. (1991). When men are the minority: The case of men in nursing. The Sociological Quarterly, 32 (3), 389-401.

https://doi.org/10.1111/j.1533-8525.1991.tb00165.x

Hochschild, A. (1983). The managed heart: Commercialisation of feeling in female-dominated occupations. Berkeley, CA: University of California Press.

Hodges, E. A., Rowsey, P. J., Gray, T. F., Kneipp, S. M., Giscombe, C. W., Foster, B. B. \& Kowlowitz, V. (2017). Bridging the gender divide:

Facilitating the educational path for men in nursing. Journal of Nursing Education, 56(5), 295-299.

https://doi.org/10.3928/01484834-20170421-08

Hollup, O. (2014). The impact of gender, culture, and sexuality on Mauritian nursing: Nursing as a non-gendered occupational identity or masculine field? Qualitative study. International Journal of Nursing Studies, 51(5), 752-760.

https://doi.org/10.1016/j.ijnurstu.2013.09.013

Jary, D., \& Jary, J. (1991). Collins Dictionary of Sociology. Glasgow: Harper Collins

Johnson, G. (1994). Letter to the Editor regarding Ryan \& Porter article. Nursing Outlook,42(5), 244.

Landivar, L. C. (2013). Men in nursing occupations: American Community Survey Highlight Report. Suitland, MD: US Census Bureau.

London, F. (1987). Should men be actively recruited into nursing? Nursing Administration Quarterly, 12(1), 75-81.

https://doi.org/10.1097/00006216-198701210-00014

Lupton, B. (2000). Maintaining masculinity: Men who do 'Women's Work'. British Journal of Management, 11(S1), 33-48.

https://doi.org/10.1111/1467-8551.11.s1.4

Lupton, B. (2006). Explaining men's entry into female-concentrated occupations: Issues of masculinity and social class. Gender, Work and Organization, 13(2), 103-128. 
334 Ajith - In the Pursuit of an Identity

\section{https://doi.org/10.1111/j.1468-0432.2006.00299.x}

Mackintosh, C. (1997). A historical study of men in nursing. Journal of Advanced Nursing, 26(2), 232-236.

https://doi.org/10.1046/j.1365-2648.1997.1997026232.x

MacPhail, J. (1996). Men in nursing. In Ken, J.R. and MacPhail, J. (Eds.), Canadian nursing: Issues and perspectives. ( $3^{\text {rd }}$ ed.) (pp. 74-81). St. Louis: Mosby-Yearbook

Mangan, E. (1994). Private lives. Nursing Times, 90(14), 60-64.

Meadus, R. J. (2000). Men in nursing: Barriers to recruitment. Nursing Forum, 35(3), 5-12.

https://doi.org/10.1111/j.1744-6198.2000.tb00998.x

Nair, S., \& Healey, M. (2008). A Profession on the margins: Status issues in Indian nursing. Working Paper, Centre for Women's Development Studies, New Delhi.

O’Lynn, C.E. (2007). Gender-based barriers for male students in nursing education programs. In C.E. O'Lynn, \& R.E. Tranbarger (Eds.), Men in nursing: History, challenges, and opportunities (pp. 169-187). New York, NY: Springer.

Percot, M. (2006). Indian nurses in the Gulf: From job opportunity to life strategy. In Agrawal, A. (Ed.), Migrant Women and Work (pp.155-176). New Delhi: Sage Publications

Percot, M. (2006a). Indian nurses in the Gulf: Two generations of female migration. South Asia Research, 26(1), 41-62. https://doi.org/10.1177/0262728006063198

Pringle, R. (1993). Male secretaries. In Williams, C.L. (Ed.), Doing 'Women's Work': Men in nontraditional occupations (pp. 128-151). London: Sage.

Purnell, L. D. (2007). Men in nursing: An international perspective. In C.E. O'Lynn, \& R.E. Tranbarger (Eds.), Men in nursing: History, challenges, and opportunities (pp. 219-235). New York: Springer.

Ramacciotti, K., \& Valobra, A. (2017). The Nightingale dilemma: controversies about the professionalization of nursing in Argentina 19491967. Dynamis, 37(2), 367-387. 
Ramacciotti, K. I. (2020). Historias de la enfermería en Argentina. Pasado y presente de una profesión. [Stories of nursing in Argentina. Past and present of a profession]. José C. Paz: Edunpaz.

https://edunpaz.unpaz.edu.ar/OMP/index.php/edunpaz/catalog/view/49/6 0/187-3

Scrinzi, F. (2010). Masculinities and the international division of care:

Migrant male domestic workers in Italy and France. Men and Masculinities, 13(1), 44-64.

https://doi.org/10.1177/1097184X10382880

Segal, B. E. (1962). Male Nurses: A case study in status contradiction and prestige loss. Social Forces, 41(1), 31-38.

Shen-Miller, D., \& Smiler, A. P. (2015). Men in Female-Dominated Vocations: a Rationale for Academic Study and Introduction to the Special Issue. Sex Roles, 72(7-8), 269-276.

https://doi.org/10.1007/s11199-015-0471-3

Simpson, R. (2004). Masculinity at work: The experiences of men. Work, Employment and Society, 18(2), 349-368.

https://doi.org/10.1177/09500172004042773

Stott, A. (2004). Issues in the socialisation process of the male student nurse: Implications for retention in undergraduate nursing courses. Nurse Education Today, 24(2), 91-97.

https://doi.org/10.1016/j.nedt.2003.09.005

Trossman, S. (2003). Caring knows no gender. AJN, American Journal of Nursing, 103(5), 65-68.

https://doi.org/10.1097/00000446-200305000-00024

Varghese, V. J., \& Rajan, S. I. (2011). Governmentality, social stigma and quazi citizenship: Gender negotiations of migrant women domestic workers from Kerala. In Rajan, S. I. and Percot, M. (Eds.), Dynamics of Indian migration: Historical and current perspectives (pp. 224-248). New Delhi: Routledge.

Villeneuve, M.J. (1994). Recruiting and retaining men in nursing: A review of the literature. Journal of Professional Nursing, 10(4), 217-228.

https://doi.org/10.1016/8755-7223(94)90023-x 
336 Ajith - In the Pursuit of an Identity

Walton-Roberts, M. (2010). Student nurses and their post-graduation migration plans: A Kerala case study. In Rajan, S. I. (Ed.), India Migration Report 2010 (pp.196- 216). New Delhi: Routledge.

Walton-Roberts, M., \& Rajan, S.I. (2013). Nurse emigration from Kerala: 'Brain circulation' or 'trap'?

In Rajan, S. I. (Ed.), India Migration Report 2013 (pp.206-223). New Delhi: Routledge

http://www.academia.edu/2335246/_Nurse_emigration_from_Kerala_Br ain_circulation_or_trap_

Williams, C. L. (1992). The glass escalator: Hidden advantages for men in the 'female' professions. Social Problems, 39(3), 253-267.

https://doi.org/10.2307/3096961

Williams, C.L. (1995). Still a man's world: Men who do women's work. Berkeley: University of California Press.

Zamanzadeh, V., Valizadeh, L., Negarandeh, R., Monadi, M., \& Azadi, A. (2013). Factors influencing men entering the nursing profession, and understanding the challenges faced by them: Iranian and developed countries' perspectives. Nursing and Midwifery Studies, 2(4), 49-56. https://doi.org/10.5812/nms.12583

Anakha Ajith is a Ph.D. Research Scholar at the Department of Anthropology, University of Hyderabad, India.

Contact Address: Direct correspondence to Anakha Ajith, Department of Anthropology, University of Hyderabad, Hyderabad, Telangana, India. PIN 500046. email: anuajith737@gmail.com 